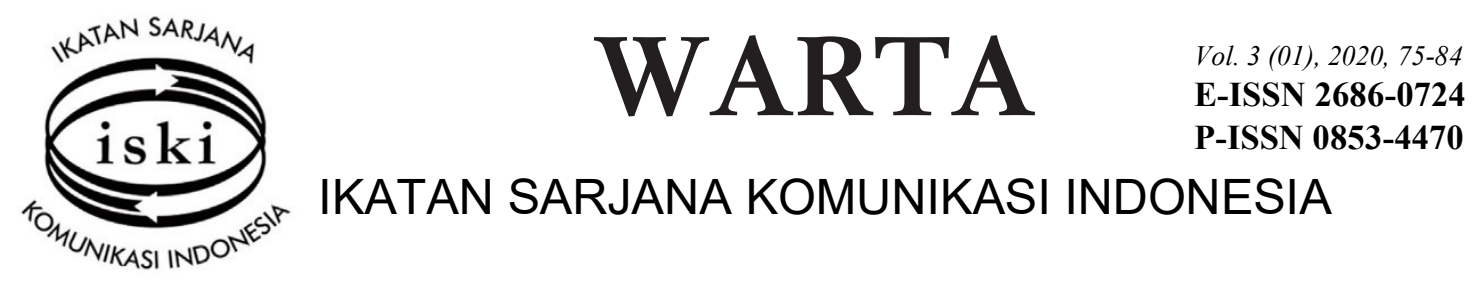

\title{
Marketing Public Relations dalam Membangun Ekuitas Merek Sepeda Motor KTM Berbasis Pelanggan
}

\author{
http://dx.doi.org/10.25008/wartaiski.v3i01.56
}

\author{
Mahrani $^{*}$ \\ ${ }^{1}$ Sekolah Tinggi Ilmu Komunikasi (STIKOM) InterStudi \\ J1 Wijaya II No 62 Jakarta 12160 - Indonesia \\ *e-mail korespondensi: Mahrani.premiummotorindo@gmail.com
}

Submitted: 13/04/2020, Revised: 05/05/2020, Accepted: 03/06/2020

Accredited by Kemristekdikti No. 30/E/KPT/2019

\begin{abstract}
Competitors are always present and serves as a challenge, with the present competitive market segment where companies do market their products and services. Likewise, competitors are present in the automotive market products such as motorcycles under the KTM brand. Therefore, Public Relations Marketing is needed as many companies consider it as an important and useful tool to present and attract customers in building KTM motorcycle brand equity through the planning stage, implementation phase and evaluation stage of programs carried out through special publications, participation in community activities to raise funds, exhibit special event sponsors, lobby and other public works to customers and build brand equity in the minds of customers. Therefore, it displays that the products produced by the company are in accordance with the demands and needs, and interests of customers. The purpose of this study is to describe Marketing Public Relations in building KTM motorcycle brand equity based on customers. This research uses a qualitative approach with descriptive methods. The key informants in this study are the CEO, and the informants are Marketing Manager, Public Relations Manager of PT PMA, and five KTM brand motorcycle customers. The results showed that through Marketing PR it can build KTM motorcycle brand equity well through programs conducted by the MPR by involving customers. This is evident that customers are satisfied and proud to own a motorcycle with the KTM brand.
\end{abstract}

Keywords: Integrated Marketing Communication; Marketing PR; Brand; Brand Equity; Customer

\begin{abstract}
Abstrak
Persaingan selalu hadir sebagai tantangan, dan menantang dengan segmen pasar tempat perusahaan melakukan pemasaran produk dan jasa. demikian juga persaingan dalam memasarkan produk otomotif seperti sepeda motor dengan merek KTM yang relatif baru di Indonesia. Oleh karena itu diperlukan Marketing Public Relations karena banyak perusahaan menganggap sebagai alat yang penting dan berguna untuk menghadirkan dan menarik pelanggan untuk membangun ekuitas merek sepeda motor KTM dilakukan melalui tahap perencanaan, tahap pelaksanaan dan tahap evaluasi program-program yang dilakukan melalui melalui publikasi khusus, partisipasi dalam kegiatan masyarakat untuk penggalangan dana, pameran sponsor acara khusus, lobi dan pekerjaan umum lainnya kepada para pelanggan dan membangun ekuitas merek di benak pelanggan dan menunjukkan bahwa produk yang dihasilkan perusahaan sesuai dengan keinginan dan kebutuhan serta minat pelanggan. Tujuan penelitian ini untuk mendeskripsikan Marketing Public Relations dalam membangun ekuitas merek sepeda motor KTM berbasis pelanggan. Pendekatan yang digunakan dalam penelitian ini adalah kualitatif dan metode penelitiannya adalah deskriptif. Informan dalam penelitian ini CEO, Marketing Manager, Public Relations Manager PT PMA, dan lima orang pelanggan sepeda motor merek KTM. Pengumpulan data dilakukan melalui tahap observasi, wawancara mendalam, dokumentasi dan penelusuran internet. Analisis data dilakukan melalui reduksi, display data, dan verikasi/kesimpulan Hasil penelitian menunjukkan bahwa Marketing PR dapat membangun ekuitas merek sepeda motor KTM dengan baik melalui program-program yang dilakukan MPR dengan melibatkan pelanggan. Hal ini terbukti bahwa para pelanggan merasa puas dan bangga memiliki sepeda motor dengan merek KTM.
\end{abstract}




\section{PENDAHULUAN}

Public Relations (PR) dalam pelaksanaannya bersifat interaktif dengan memanfaatkan berbagai alat komunikasi sehingga dampaknya dapat diukur menggunakan berbagai jenis komunikasi. Fokus dari aktivitas PR adalah untuk memperoleh pengertian dari publik sehingga dapat mempengaruhi pendapat publik. The Mexican Statement menyatakan praktik PR sebagai sebuah seni, sekaligus ilmu sosial yang menganalisis berbagai tren, memperkirakan setiap kemungkinan dari konsekuensi, memberikan masukan dan saran kepada pemimpin organisasi, dan mengimplementasikan tindakan dari programprogram yang direncanakan: melayani kebutuhan organisasi dan kepentingan publik (Butterick, 2011).

Aspek terpenting dari definisi ini ada pada kata menganalisis tren (kecenderungan) yang mengisyaratkan penerapan teknik-teknik riset sebelum merencanakan suatu program atau kampanye PR. Kemudian menerapkan aspek penting lainnya yaitu ilmu sosial dari suatu organisasi, yakni tanggung jawab organisasi atas kepentingan publik atau kepentingan masyarakat luas. Setiap organisasi dinilai berdasarkan aspek terjangnya. Jadi, PR berkaitan dengan niat baik dan nama baik (reputasi).

PR adalah fungsi manajemen perusahaan yang berkontribusi pada pembentukan kondisi yang menguntungkan untuk komunikasi dan menciptakan saling pengertian, dapat menerima, dan koordinasi antara perusahaan dengan publiknya (Todorova, 2015). Sebagai fungsi manajemen seorang petugas PR harus memiliki keahlian sebagai Creator, Conseptor, Mediator, Problem Solver (Poppy, 2014). Hasil penelitian yang dilakukan oleh Ukaj (2016) menunjukkan, PR memiliki identitas dan cara komunikasi yang spesifik dengan publik. Pelanggan setia perusahaan dan sebagian besar PR digunakan sebagai elemen komunikasi Integrated Marketing Communication (IMC) sebagai perpaduan antara pemasaran dan PR yang dikenal dengan MPR.

Perusahaan importir dan agen pemegang merek (APM) memasarkan produk sepeda motor dengan nama brand KTM di Indonesia menggunakan Marketing Public Relations (MPR) sebagai alat untuk membangun ekuitas merek. Schultz (dalam Keller, 2013) berpendapat ekuitas merek tidak hanya dibangun melalui bentuk komunikasi individu seperti promosi, iklan, public relations atau pemasaran langsung tetapi juga dengan mengelola kontak ekuitas merek oleh MPR yang dijadikan alat untuk menyebarkan informasi, mempengaruhi, dan memikirkan pelanggan langsung dan tidak langsung yang dilakukan dengan efisien dan terjangkau secara finansial (Papasolomou et al., 2014).

MPR memainkan peran penting dalam proses peluncuran produk baru serta reposisi produk. MPR dapat membangun minat, mempengaruhi kelompok sasaran tertentu, mempertahankan produk yang mengalami masalah publik, dan membangun citra perusahaan yang mencerminkan layanan produknya (Kotler \& Keller, 2009, Papasolomou et al., 2014). MPR juga berperan dalam membentuk ekuitas merek.

Sementara itu banyak penelitian telah dilakukan untuk mengidentifikasi tingkat kesadaran merek di sektor bisnis. Salah satunya adalah survei di antara 286 pelanggan Ad Age yang memegang posisi pemasaran dan periklanan dengan organisasi klien. Temuannya adalah: (1) MPR dianggap efektif dalam berbagai bidang yang secara tradisional merupakan tanggung jawab iklan: (2) MPR sangat efektif dalam membangun kesadaran merek dan pengetahuan merek; (3) MPR melengkapi iklan dengan meningkatkan kredibilitas pesan; (4) MPR dibuat hemat biaya dengan kenaikan biaya iklan media (Papasolomou et al., 2014).

Selain itu, penelitian ini secara konseptual mengembangkan temuan empirisnya untuk membangun kerangka kerja MPR yang berfokus pada pelanggan dalam konteks pemasaran strategis (Papasolomou et al., 2014).

Penelitian Minna (2012) di tiga perusahaan menunjukkan, MPR dapat memiliki dampak yang kuat pada kesadaran publik dengan biaya jauh lebih rendah daripada yang dapat diiklankan. Meskipun MPR hanya menggunakan sebagian kecil dari anggaran pemasaran perusahaan, MPR diakui sebagai alat untuk membangun ekuitas merek yang kuat. Kemudian (Laurencia \& Setyanto, 2019) menjelaskan strategi Public Relations dalam menghadapi persaingan bisnis otomotif yang semakin ketat. Hasil penelitian mendeskripsikan bahwa seluruh strategi Public Relations digunakan dalam menghadapi para competitor, tetapi dalam penyusunan strategi Public Relations melibatkan banyak pihak sehingga perusahaan membagi tugas berdasarkan keahlian masing-masing agar berjalan dengan efektif.

Temuan penelitian (Widikusyanto, 2017) menunjukkan MPR memiliki banyak keunggulan dibandingkan advertising dalam membangun merek walaupun masih banyak perusahaan yang 
Warta Ikatan Sarjana Komunikasi Indonesia

e-ISSN: 2686-0724 - p-ISSN: 0853-4470 - Vol. 3, No. 01 (2020), pp. 75-84

membangun merek barunya menggunakan advertising. Namun dari berbagai bukti praktis dan dukungan dari banyak ahli pemasaran, MPR menjadi sarana yang tepat bagi setiap perusahaan yang ingin membangun merek-nya.

Selanjutnya hasil temuan penelitian yang dilakukan oleh Puspita menunjukkan penggunaan alat Marketing Public Relations yaitu Social Media, Website, Partnership, Event/Campaign, Sponsor dan pidato dalam serangkaian acara (Puspita, 2019, Hutagalung, 2018). Penelitian lain yang dilakukan (Wicaksono et al., 2014) fokus pada semua elemen komunikasi pemasaran terpadu dalam mempengaruhi ekuitas merek, menjelaskan pengaruh komunikasi pemasaran secara bersama-sama maupun sendiri-sendiri.

Selanjutnya penelitian (Krussell \& Paramita, 2016) menunjukkan, dimensi komunikasi pemasaran terpadu terdiri dari Periklanan, Promosi Penjualan, Penjualan Pribadi, Hubungan Masyarakat, Pemasaran Langsung, Pemasaran Interaktif, dan Desain Perusahaan secara bersama-sama memengaruhi ekuitas merek, sementara secara parsial, hanya Promosi Penjualan, Penjualan Pribadi, dan Desain perusahaan yang secara signifikan memengaruhi Brand Equity.

Merujuk pada beberapa hasil penelitian tersebut, persamaannya sama-sama menggunakan MPR tetapi penelitian yang dilakukan oleh Wicaksono berbeda karena lebih fokus pada seluruh unsur-unsur IMC tetapi sama-sama menggunakan ekuitas merek. Perbedaan dengan penelitian sebelumnya dengan penelitian ini terletak pada tujuan penelitian yaitu mendeskripsikan Marketing Public Relations dalam membangun ekuitas merek berbasis pelanggan.

\section{KERANGKA TEORI}

Komunikasi pemasaran yang dirancang sejak awal dengan pelanggan sifatnya interaktif dengan segmentasi sasaran berbagai produk yang dihasilkan beserta kualitas pelayanannya. Pelaku pasar harus memberikan penilaian pengalaman dan daya tarik yang berdampak dalam proses pembelian merek. Pengertian ini akan menolong mereka untuk menerapkan komunikasi dengan efektif dan merencanakan serta melaksanakan jenis program yang terarah dan tepat. Berbekal wawasan ini pelaku pasar dapat memperkirakan atau menilai sesuai dengan kemampuannya sehingga dapat berpengaruh pada kesan dan pengalaman membentuk ekuitas merek dan memotivasi penjualan produk.

Menurut Duncan \& Caywood (1996) integrated marketing communication (IMC) adalah konsep perencanaan komunikasi pemasaran yang melakukan evaluasi dan berperan secara strategis dari bermacam disiplin ilmu komunikasi, seperti periklanan, public relations, sales promotiom, dengan menggabungkan berbagai komunikasi untuk menginformasikan secara jelas, konsisten pemasaran suatu produk (Kliatchko, 2005). Sedangkan Kotler (2007) menjelaskan, IMC merupakan suatu proses rancangan yang menyeluruh untuk membuat evaluasi strategis dengan melibatkan setiap unsur komunikasi pemasaran yang terdiri dari advertising, direct sales, sales promotion, public relations, interactive marketing. Definisi itu menekankan perlunya rencana komunikasi pemasaran menggunakan beberapa alat komunikasi pemasaran, dan memanfaatkan kekuatan masing-masing, dengan tujuan mencapai dampak komunikasi.

Berdasarkan konsep IMC yang dikemukakan Kotler, peneliti hanya fokus pada unsur public relations yang kemudian dikenal dengan istilah Marketing Public Relations (MPR). Istilah MPR merupakan penggabungan dari dua fungsi yaitu: "Marketing" atau Pemasaran dan "Public Relations". Dari kedua istilah ini menunjukkan adanya hubungan antara aktivitas keduanya yang saling mempengaruhi satu sama lain. Hal ini diperkuat oleh pendapat (Batra \& Keller, 2016) yang mengemukakan perlu adanya pilihan dalam strategi komunikasi pemasaran terpadu dalam membangun ekuitas merek.

\section{Marketing Public Relations}

Payung dari MPR adalah Integrated Marketing Communication (IMC). Efek IMC pada ekuitas merek dilihat dari perspektif ekuitas merek berbasis pelanggan dengan kegiatan komunikasi pemasaran berkontribusi untuk mendorong penjualan dan ekuitas merek (Keller 2007), membentuk pentingnya merek; mengaitkan organisasi atau asosiasi yang baik, dan menanamkan pikiran dalam diri pelanggan sehingga menciptakan citra merek serta memfasilitasi hubungan konsumen dengan merek yang lebih kuat. Cara pembentukan asosiasi merek tidak penting, tetapi yang terpenting adalah aktivitas komunikasi pemasaran harus dipadukan untuk menyampaikan informasi terarah guna memperoleh kedudukan yang tepat dan strategis. 
Warta Ikatan Sarjana Komunikasi Indonesia e-ISSN: 2686-0724 - p-ISSN: 0853-4470 - Vol. 3, No. 01 (2020), pp. 75-84

Kitchen (2010), mengatakan MPR memiliki potensi untuk menjadi alat utama dalam komunikasi pemasaran terpadu karena kemampuan umum Public Relations untuk berkontribusi dalam mencapai tujuan pemasaran. MPR adalah program yang bertujuan melindungi atau meningkatkan citra merek dan membangun penjualan merek dengan mendorong sejumlah perantara (konektor) misalnya media massa tradisional, media elektronik, pemimpin opini, dan konsumen untuk secara sukarela menyampaikan pesan tentang perusahaan (Papasolomou \& Melanthiou, 2012). Sementara itu, Kotler (2003) seperti dikutip Widikusyanto (2017):

“...building a new brand through PR is better than using advertising even though it requires more creativity and more time. Companies that plan to build new brands need to create buzz, and buzz is created through PR tools. Using a PR campaign will cost you far less and allow you to create a more lasting story"

Definisi MPR menurut Thomas L. Harris (1993) dikutip Ruslan (2010):

“... a process of planning, implementing and evaluating programs that can generate buying interest and create customer satisfaction, which is carried out through an information and impression process that attracts customers to show that the products produced by the company are in accordance with the wants and needs and interests of customers".

Giannini (2010) menambahkan MPR sebagai:

"...any program or effort designed to enhance, maintain or protect the sale or image of a product by encouraging intermediaries such as traditional mass media, electronic media, or individuals to voluntarily deliver messages about the company or product to their business or consumer audience" (Papasolomou \& Melanthiou, 2012).

Dengan demikian MPR adalah kegiatan informasi mengenai produk dengan menggunakan strategi pengemasan pesan yang efektif, ditujukan kepada pelanggan melalui tahap perencanaan, pelaksanaan dan evaluasi. Serangkaian aktivitas tersebut bertujuan untuk memberikan nilai tambah terhadap produk sehingga dapat menciptakan sebuah citra produk (brand image) yang baik, kesadaran konsumen terhadap merek (brand awareness), serta ekuitas merek (brand equity). Upaya ini pada akhirnya sangat menunjang dan mendukung pencapaian tujuan pemasaran yang dilakukan oleh perusahaan sehingga terjadi peningkatan penjualan serta terciptanya loyalitas konsumen terhadap sebuah produk.

Posisi MPR dalam suatu organisasi atau perusahaan dianggap penting dan efektif karena beberapa alasan: (1) MPR dinilai dapat membangun kesadaran merek dan pengetahuan tentang produk di mata pelanggan; (2) MPR dinilai potensial dalam menciptakan pada wilayah "meningkatkan penggunaan kategori dan meningkatkan penjualan produk"; (3) perusahaan yang memanfaatkan MPR dapat menghemat biaya jika dibandingkan menggunakan iklan dalam memasarkan produk (Papasolomou et al., 2014).

\section{Peran MPR}

Menurut Kotler dan Keller (2006) MPR berperan dalam upaya mencapai tujuan utama organisasi yang telah ditetapkan. Adapun tujuan dari MPR adalah sebagai berikut: (1) membentuk dan mengembangkan adanya kesadaran konsumennya terhadap merek produk yang dipromosikan; (2) membentuk rasa percaya pelanggan memperoleh citra dan manfaat produk yang ditawarkan; (3) memotivasi artikel sponsor (advertorial) mengenai manfaat suatu produk; (4) memberi tekanan pada biaya promosi melalui iklan komersial dengan menggunakan media massa untuk efisiensi biaya; (5) memiliki kesepakatan dalam meningkatkan pelayanan kepada konsumen demi tercapainya kepuasan pihak pelanggan; (6) memberi bantuan dalam kampanye produk yang diluncurkan dan juga membuat rencana perubahan produk lama; (7) menginformasikan secara berkelanjutan menggunakan media Public Relations tentang kegiatan yang berhubungan dengan kondisi sosial dan lingkungan hidup untuk memperoleh publikasi yang baik di mata publik; (8) mengelola dan memperkuat corporate image dan atau produk barang dan jasa, dan memberikan kualitas pelayanan pelanggan. Berusaha dengan aktif untuk menyelesaikan suatu peristiwa negatif jika timbul pada masa yang akan datang (Ruslan, 2010). 
Warta Ikatan Sarjana Komunikasi Indonesia

e-ISSN: 2686-0724 - p-ISSN: 0853-4470 - Vol. 3, No. 01 (2020), pp. 75-84

Sedangkan Philip Kotler dan Kevin Lane Keller (2009) mengemukakan ada tujuh strategi atau cara yang dapat dijadikan alat untuk mengukur dalam melaksanakan kegiatan MPR: publikasi, identitas media, acara, berita, pidato, kegiatan layanan publik, sponsor (Kotler \& Keller, 2009)

\section{Ekuitas Merek}

Merek merupakan langkah pertama dalam membangun ekuitas merek. Aaker (1992) menjelaskan merek sebagai nama dan atau simbol pembeda (seperti logo, merek dagang, atau desain paket) berfungsi untuk mengidentifikasi produk penjualan, dan membedakan produk perusahaan dari milik pesaing (Soebiagdo \& Ruliana, 2017). Definisi ini berfokus pada keunggulan obyektif terukur dari suatu produk, dan konsumen dapat melihat kinerja produk.

Kebanyakan pelanggan dalam berbagai kondisi mempertimbangkan arti merek atau nilai merek Membangun makna merek mengikutsertakan pembentukan kesan dari merek yang dicirikan oleh merek. Walaupun berbagai jenis hubungan atau asosiasi produk atau merek dimungkinkan, makna merek dapat didiferensiasi secara luas dalam hal fungsi, mempertimbangkan performa dengan mempertimbangkan merek yang sifatnya unik. Makna merek dapat dikatakan memiliki dua kategori yaitu hubungan merek yang ada di pikiran konsumen dan kesan dengan seperangkat kategori spesifik (Keller, 2001).

Dari perspektif ekuitas merek berbasis pelanggan, kegiatan komunikasi pemasaran berkontribusi terhadap peningkatan penjualan dan ekuitas merek dengan membangun rasa sadar terhadap merek; mengaitkan organisasi atau asosiasi yang baik sehingga dapat meningkatkan produk dengan citra yang baik di pikiran pelanggan (Keller, 2001). Kebanyakan pelanggan dalam berbagai kondisi dengan mempertimbangkan hal lainnya, misalnya arti merek atau nilai merek, turut memiliki peran. Membangun makna merek dengan mengikutsertakan pembentukan kesan dari merek yang dicirikan oleh merek, penting diperjuangkan dan dipikirkan konsumen atau pelanggan. Walaupun berbagai jenis hubungan atau asosiasi produk atau merek dimungkinkan, makna merek dapat didiferensiasi secara luas dalam hal fungsi, mempertimbangkan terkait performa dengan mempertimbangkan merek yang sifatnya unik, terkait kesan. Jadi , makna merek dapat dikatakan memiliki dua kategori yaitu hubungan merek yang ada di pikiran konsumen atau pelanggan sehubungan dengan performa dan kesan dengan seperangkat beberapa kategori spesifik di masing-masingnya (Keller, 2001).

Ekuitas merek berbasis pelanggan menurut Keller adalah dampak yang berbeda dari product knowledge pada reaksi pelanggan terhadap merek yang dipasarkan. Ini melibatkan reaksi pelanggan terhadap komunikasi pemasaran terpadu yang berkaitan dengan merek dibandingkan dengan reaksi pelanggan terhadap unsur-unsur dalam komunikasi pemasaran terpadu yang sama terkait dengan versi produk atau layanan yang disebutkan secara fiktif atau anonim. Pelanggan terbiasa dengan merek dan memiliki beberapa asosiasi penyimpanan merek yang kuat, unik dan bermanfaat akan membangun ekuitas merek berbasis pelanggan (Keller, 2009).

Mengintegrasikan komunikasi pemasaran dengan demikian melibatkan kombinasi dan kesesuaian dalam memilih komunikasi yang memiliki perbedaan dalam membentuk rasa sadar dan citra sesuai dengan citra yang diharapkan dalam benak konsumen (Keller, 2009). Hal ini berkaitan dengan langkah-langkah membangun merek. Langkah pertama identitas merek terbangun dengan tepat. Langkah kedua, makna mereka diciptakan dengan sesuai. Langkah ketiga, menimbulkan reaksi merek dengan baik. Langkah terakhir membina relasi dengan pelanggan tentang merek

\section{Pelanggan}

Salah satu sasaran dari kegiatan marketing PR dalam membangun ekuitas merek adalah pelanggan. Greenberg (2010) mengemukakan pengertian pelanggan merupakan individu atau kelompok yang membeli produk atau jasa dengan mempertimbangkan berbagai faktor, misalnya kualitas, harga, lokasi, service yang diberikan perusahaan. Steve (2011) mengemukakan, pelanggan adalah orang atau perusahaan yang menerima, mengonsumsi produk atau layanan dan dapat memilih antara barang dan pemasok yang berbeda. Tujuan utama dari semua perusahaan komersial adalah menarik pelanggan atau klien, dan membuat mereka membeli apa yang mereka jual.

Inti dari pemasaran adalah memiliki pemahaman yang baik tentang kebutuhan dan nilai pelanggan (dalam laman web MBN, 2020). Pelanggan penting karena mereka mendorong pendapatan; tanpa mereka, bisnis tidak memiliki apa-apa untuk ditawarkan. Sebagian besar bisnis yang dihadapi 

oleh publik bersaing dengan perusahaan lain untuk menarik pelanggan dengan menggunakan berbagai strategi komunikasi pemasaran.

Bisnis sering menghormati pepatah "the customer is always right " karena pelanggan yang bahagia cenderung memberikan bisnis berulang kepada perusahaan yang memenuhi atau melampaui kebutuhan mereka. Akibatnya, banyak perusahaan memonitor hubungan pelanggan mereka untuk memberikan umpan balik tentang metode untuk meningkatkan lini produk.

Pelanggan dikategorikan dalam banyak cara. Paling umum, pelanggan diklasifikasikan sebagai eksternal atau internal. Pelanggan eksternal dipisahkan dari operasi bisnis dan seringkali merupakan pihak yang tertarik untuk membeli barang dan jasa akhir yang diproduksi oleh perusahaan. Pelanggan internal adalah individu atau bisnis yang diintegrasikan ke dalam operasi bisnis, sering kali ada sebagai karyawan atau kelompok fungsional lainnya dalam perusahaan.

\section{METODE PENELITIAN}

Penelitian ini menggunakan pendekatan kualitatif untuk mengeksplorasi dan memahami makna individu atau kelompok yang berkaitan Marketing Public Relations dalam membangun ekuitas merek sepeda motor KTM. Proses penelitian melibatkan pertanyaan dan prosedur yang muncul, data dikumpulkan dalam pengaturan peserta, analisis data secara induktif membangun dari rincian ke tema umum, dan peneliti membuat interpretasi tentang makna data (Creswell, 2007).

Metode penelitian yang digunakan adalah deskriptif untuk menggambarkan fenomena yang terjadi dalam kehidupan nyata (Yin, 2014). Marshal dan Rossman menjelaskan, untuk mendalami setting peneliti, digunakan deskriptif pelaku riset mendatangi dunia informan melalui hubungan yang berkesinambungan untuk menggali makna dan pandangan dari informan utama (Creswell, 2013).

Informan kunci adalah Direktur PT. PMA, CEO PT. PMA dan informan Manajer Pemasaran dan public relations PT PMA serta lima pelanggan yang menggunakan sepeda motor merek KTM. Mereka dipilih karena memiliki kompetensi sesuai dengan bidang keahliannya dan memiliki pengalaman dalam merencanakan, melaksanakan dan mengevaluasi suatu program MPR.

Pengumpulan data dilakukan melalui tahap wawancara mendalam, tahap observasi partisipan dan tahap dokumentasi, yaitu data yang tersedia tersebut sebagian besar berbentuk surat-suratan, catatan, laporan, foto. Data ini memberi peluang kepada peneliti untuk mengetahui secara detail bahan dokumentasi, seperti, kliping, dokumen, company profile serta penelusuran melalui internet atau website, atau server dan lain-lain (Bungin, 2010).

Teknik analisis data menggunakan model interaktif dari Miles dan Huberman melalui tiga langkah. Pertama melakukan reduksi data, kedua menyajikan data, dan ketiga melakukan verifikasi atau kesimpulan (Sugiyono, 2016).

\section{HASIL PENELITIAN}

Perencanaan yang dilakukan oleh MPR PT. PMA adalah terlebih dahulu melakukan riset lapangan kepada konsumen yang dituju untuk memperoleh fakta di lapangan. Perencanaan ini mendapat dukungan penuh dari pimpinan dan teamwork. Adapun fakta yang ditemukan menurut MPR adalah sebagai berikut:

Pertama, semakin berkembangnya dunia otomotif di Indonesia maka semakin tinggi dan semakin besar pula tingkat kompetisinya. Kedua, ada potensi pasar yang baru terutama di kalangan anak muda, orang tua dan komunitas sepeda motor merek KTM jenis offroad yang bisa dijadikan sebagai target strategi komunikasi pemasaran.

Fakta tersebut dijadikan peluang besar untuk memasarkan produk sepeda motor KTM dengan target sasaran kalangan anak muda, orang tua dan komunitas motor offroad, dengan melihat adanya peluang bisnis pada sektor otomotif jenis offroad dan street bike. Pasar itu sangat diminati oleh komunitas di Indonesia sebagai motor "Lifestyle". Tahap identifikasi dilakukan PT PMA dengan melakukan observasi terhadap perkembangan dunia otomotif yakni belum ada perusahaan importir yang mendistribusikan brand motobike "KTM" di Indonesia.

Berdasarkan fakta tersebut penting dilakukan penyusunan perencanaan jangka pendek. Adapun tujuannya dari perencanaan jangka pendek menurut MPR adalah membangun kesadaran merek KTM di Indonesia, mempertahankan citra merek KTM dan membangun kepercayaan pelanggan sehingga dapat meningkatkan jumlah penjualan produk. 
Warta Ikatan Sarjana Komunikasi Indonesia e-ISSN: 2686-0724 - p-ISSN: 0853-4470 - Vol. 3, No. 01 (2020), pp. 75-84

Rencana jangka pendek tersebut disusun untuk merencanakan program promosi secara masif dengan memaksimalkan strategi marketing mix, aktif mengikuti pameran dan event otomotif, merencanakan media massa yang diklasifikasikan sebagai above the line, below the line, dan out door media serta internet untuk promosi. Di samping itu, mempersiapkan naskah pidato dan press release yang diberikan kepada wartawan pada event tersebut.

Perencanaan program yang dilakukan oleh PMA tersebut dengan mengedepankan identitas merek sepeda motor merek KTM. Perencanaan program itu diharapkan memiliki daya tarik pelanggan sehingga mau membeli sepeda motor dengan identitas merek berbeda dengan sepeda motor lainnya. Identitas merek sepeda motor KTM menurut CEO PT PMA adalah sebagai berikut:

"Identitas merek sepeda motor KTM yang paling utama adalah warna khas KTM, yaitu kombinasi warna hitam dan orange, sixdays edition dan design produk yang inovatif. Warna orange sudah menjadi ciri khas KTM selama dua dekade. Warna ini juga melambangkan slogan KTM yaitu "Ready to Race". Dalam dunia sepeda motor, KTM orange memiliki arti yang sama dengan "Ferrari Red" untuk mobil. Image yang dilihat oleh customer ketika melihat motor berwarna orange adalah KTM.

PT PMA selaku importir sepeda motor KTM yang melakukan koordinasi dengan perusahaan induk KTM di Austria, telah membuat makna merek penting untuk memperhatikan keterlibatan citra merek yang akan menjadi ciri khas merek dan harus diperjuangkan dalam pikiran pelanggan. Meskipun berbagai macam merek dimungkinkan, makna merek secara fungsional, dapat dibedakan secara luas dengan mempertimbangkan kinerja terkait citra. Identitas warna sepeda motor merek KTM dapat di lihat pada Gambar 1:

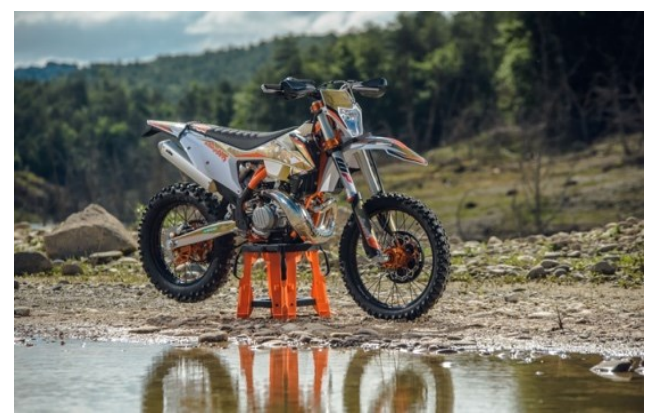

Gambar 1: Sepeda motor merek KTM Sumber: PT PMA

Dengan demikian apa yang dikemukakan oleh Keller (2001) mengenai Customer-Based Brand Equity (CBBE), membentuk merek yang baik dan kuat harus melalui beberapa langkah. Pertama identitas merek terbangun dengan tepat, kedua, makna mereka diciptakan dengan sesuai. Langkah ketiga, menimbulkan reaksi merek dengan baik. Langkah terakhir membina relasi dengan pelanggan tentang merek (Keller, 2001) memiliki relevansi dengan perencanaan program membangun sepeda motor merek KTM.

Langkah selanjutnya dalam membangun ekuitas merek adalah melaksanakan berbagai event seperti, pameran sepeda motor IIMS (Indonesia International Motor Show) dan acara Motorcross Grandprix di Indonesia (Gambar 2 dan 3).

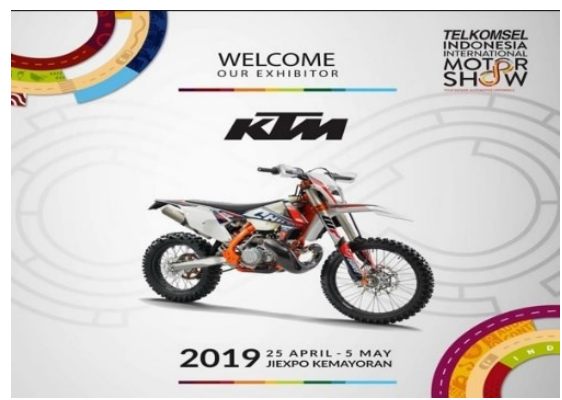

Gambar 2: Publikasi KTM di IIMS 2019 Sumber : PT PMA

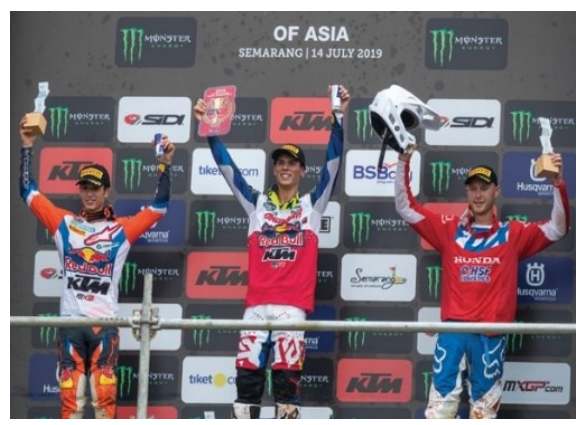

Gambar 3: Kejuaraan MXGP Sumber: PT PMA 
Warta Ikatan Sarjana Komunikasi Indonesia e-ISSN: 2686-0724 - p-ISSN: 0853-4470 - Vol. 3, No. 01 (2020), pp. 75-84

Media yang digunakan dalam acara tersebut adalah media lini atas (above the line), menggunakan media radio dan televisi juga menyiarkan secara langsung acara event MXGP (Motocross Grand Prix). Selanjutnya menggunakan media lini bawah (below the line), seperti brosur atau pamflet, souvenir, out door media seperti, banner, baliho, billboard, videotron serta media sosial Facebook, Instagram, Twitter dan website. Penggunaan media tersebut dianggap berpengaruh terhadap pelaksanaan event IIMS (Indonesia International Motor Show). Dengan diselenggarakannya event tersebut, prestasi penjualan yang diraih PMA cukup meningkat setelah tiga tahun berturut-turut menjadi sponsor dan partner penyelenggaraan MXGP, serta mendapat penghargaan sebagai stand terbaik pada IIMS 2019.

Penyelenggaraan event tersebut merupakan strategi promosi pemasaran yang dilakukan MPR dengan menyampaikan pesan-pesan mengenai produk sepeda motor KTM kepada khalayak baik secara langsung maupun tidak langsung untuk membangun ekuitas merek sepeda motor KTM. Hal ini sesuai dengan pendapat Giannini (2010) bahwa MPR sebagai program yang dirancang untuk meningkatkan, mempertahankan, atau melindungi penjualan atau citra suatu produk dengan mendorong perantara seperti media massa tradisional, media elektronik, atau individu untuk secara sukarela menyampaikan pesan tentang perusahaan atau produk kepada audiens bisnis atau konsumen mereka.

Salah satu sasaran kegiatan MPR dalam membangun ekuitas merek sepeda motor KTM adalah pelanggan. Pelanggan penting karena mereka mendorong pendapatan; tanpa mereka, bisnis tidak memiliki apa-apa untuk ditawarkan. Sebagian besar bisnis yang dihadapi oleh publik bersaing dengan perusahaan lain untuk menarik pelanggan dengan menggunakan berbagai strategi komunikasi pemasaran. Pada even pameran IIMS, pihak PMA mengundang para pelanggan dan pemangku kepentingan untuk berpartisipasi, seperti yang dikemukakan informan AS, RP, MG, DTP dan YA. Mereka mengatakan menghadiri undangan program acara yang diselenggarakan APM selain acara IIMS. Mereka juga diundang dalam acara seperti $M X G P$ dan beberapa kejuaraan nasional. Bahkan MG menjadi salah satu peserta dari acara tersebut (Gambar 4).

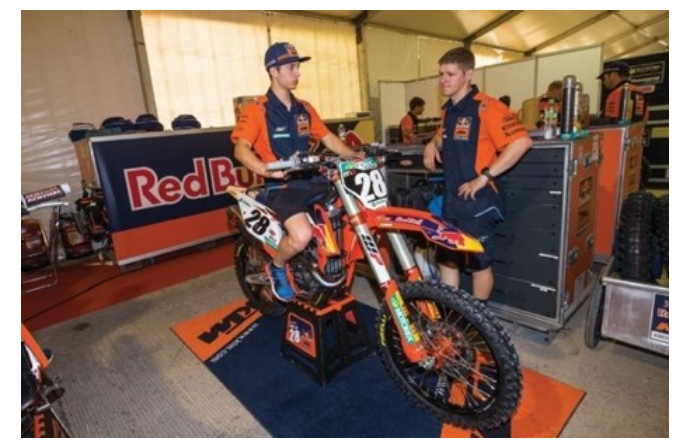

Gambar 4: Pelanggan peserta MXGP

Sumber : PT PMA

Keterlibatan pelanggan dalam acara tersebut mencerminkan bahwa PT PMA memonitor hubungan dengan pelanggan untuk mendapatkan umpan balik, dengan cara mendirikan komunitas motor KTM sebagai suatu strategi komunikasi untuk meningkatkan lini produk sepeda motor merek KTM dan para pelanggan merasa bangga memiliki sepeda motor KTM, seperti dikemukakan para informan. Mereka bangga karena banyak pembalap top dunia seperti menggunakan motor tersebut.

Kebanggaan mereka dalam menggunakan motor KTM mencerminkan perasaan terhadap merek sebagai respon dari pelanggan. Ini sesuai dengan pendapat Keller (2009) bahwa perasaan merek adalah tanggapan dan tindakan secara emosi dari pelanggan dalam kaitannya dengan merek.

Evaluasi untuk mengetahui tingkat keberhasilan seluruh program yang dilaksanakan MPR, dilakukan dengan cara memberikan kuesioner penilaian atau opini tentang sepeda motor merek KTM kepada para pelanggan.

Hasilnya, secara keseluruhan pelaksanaan kegiatan dengan melibatkan stakeholders khususnya pelanggan, memiliki daya tarik tersendiri dan kepuasan pelanggan terhadap merek KTM. Hal ini mendeskripsikan bahwa MPR memiliki keahlian dan kemampuan dalam mengkomunikasikan program pemasaran sepeda motor merek KTM, dan PMA memanfaatkan MPR sebagai salah satu strategi IMC yang dinilai efektif dan efisien. 


\section{KESIMPULAN}

Marketing Public Relations dalam membangun ekuitas merek sepeda motor merek KTM memiliki peran penting. Pelaksanaannya dilakukan melalui tahap perencanaan, pelaksanaan dan evaluasi dengan berbagai program atau event seperti IIMS (Indonesia International Motor Show) dan menjadi sponsor kegiatan event MXGP (Motocross Grand Prix) serta menggunakan media above the line, below the line, out door media.

Selain itu digunakan juga platform media sosial, media digital untuk promosi dan penyebarluasan informasi kegiatan yang diselenggarakan MPR PMA dengan melibatkan konsumen, khususnya pelanggan yang dapat dijadikan addet value dalam membangun brand equity dan citra produk di benak pelanggan sepeda motor KTM di Indonesia. Hal ini terbukti bahwa para pelanggan merasa puas dan bangga memiliki sepeda motor merek KTM karena digunakan oleh para pembalap dunia.

Serangkaian aktivitas tersebut bertujuan untuk memberikan nilai tambah sehingga dapat menciptakan citra produk atau brand image dan menumbuhkan kesadaran konsumen terhadap merek, serta ekuitas merek. Upaya ini pada akhirnya sangat menunjang dan mendukung pencapaian tujuan pemasaran yang dilakukan sehingga terjadi peningkatan penjualan, serta terciptanya loyalitas pelanggan terhadap sepeda motor merek KTM, artinya ada kesadaran merek brand image dan brand awareness.

\section{DAFTAR PUSTAKA}

Batra, R., \& Keller, K. L. (2016). Integrating Marketing Communications: New Findings, New Lessons, and New Ideas. Journal of Marketing, 80(6), 122-145. https://doi.org/10.1509/jm.15.0419

Bungin. (2010). Metodologi Penelitian Kuantitatif. Kencana Prenada Media Group.

Butterick, K. (2011). Introducing Public Relations: Theory and Practice: Live. Los Angeles : SAGE Publications Ltd. 2011. https://doi.org/10.13203/j.whugis2013.10.020

Creswell, J. W. (2007). Research Design: Qualitative, Quantitative and Mixed Method Aproaches. SAGE Publications. https://doi.org/10.4135/9781849208956

Creswell, J. W. (2013). Qualitative Inquiry and Research Design. In Qualitative Inquiry and Research Design.

Hutagalung, I. \& Ritonga, R. (2018). Pengaruh Iklim Komunikasi dan Komitmen Organisasi terhadap Kepuasan Kerja Pegawai Kecamatan XYZ Bekasi. Jurnal Kajian Komunikasi, 6(2), 72-84.

Hutagalung, I. (2018). Ambassador Produk dan Perubahan Sikap: Studi Kasus Pengolahan Iklan Kosmetik XYZ Berdasarkan Pendekatan Teori ELM di Kalangan Remaja Putri Kelurahan Rawa Buaya - Jakarta Barat. Warta Ikatan Sarjana Komunikasi Indonesia, 1(1), 1-8.

Keller, K. L. (2001). Building Customer-Based Brand Equity : A Blueprint for Creating Strong Brands Building Customer-Based Brand Equity: A Blueprint for Creating Strong Brands. Journal of Marketing Communications. https://doi.org/10.1080/13527260902757530

Keller, K. L. (2009). Building Strong Brands in a Modern Marketing Communications Environment. Journal of Marketing Communications. https://doi.org/10.1080/13527260902757530

Kliatchko, J. (2005). Towards a New Definition of Integrated Marketing Communications (IMC). International Journal of Advertising. https://doi.org/10.1080/02650487.2005.11072902

Kotler, P., \& Keller, K. L. (2009). Manajemen Pemasaran Jilid 1.

Krussell, J. G. H., \& Paramita, E. L. (2016). Komunikasi Pemasaran Terpadu dan Ekuitas Merek Alfamart. Benefit: Jurnal Manajemen Dan Bisnis. https://doi.org/10.23917/benefit.v1i1.2363

Laurencia, E., \& Setyanto, Y. (2019). Strategi Public Relations PT X dalam Menghadapi Persaingan Bisnis Otomotif. Prologia. https://doi.org/10.24912/pr.v3i2.6412

Minna, C., Sarén, H., Parikka, M., \& Sandell, C. (2012). Public Relations ' Role in Building Strong Brands.

Papasolomou, I., \& Melanthiou, Y. (2012). Social Media: Marketing Public Relations' New Best Friend. Journal of Promotion Management. https://doi.org/10.1080/10496491.2012.696458

Papasolomou, I., Thrassou, A., Vrontis, D., \& Sabova, M. (2014). Marketing Public Relations: A Consumer-Focused Strategic Perspective. Journal of Customer Behaviour. https://doi.org/10.1362/147539214x14024779343631

Puspita, I. M. (2019). Marketing Public Relation Peremajaan Merek sebagai Strategi Pemasaran dalam Membangun Citra Produk Baru. Warta Ikatan Sarjana Komunikasi Indonesia, 2(01), 19-26. https://doi.org/10.25008/wartaiski.v2i01.24

Ruliana Poppy. (2014). Komunikasi Organisasi: Teori dan studi Kasus. Jakarta: Rajawali Pers. 
Warta Ikatan Sarjana Komunikasi Indonesia e-ISSN: 2686-0724 - p-ISSN: 0853-4470 - Vol. 3, No. 01 (2020), pp. 75-84

Ruslan, R. (2010). Manajemen Public Relations dan Media Komunikasi. Jakarta: Rajawali Pers.

Soebiagdo, S., \& Ruliana, P. (2017). Pengaruh Strategi Promosi Stikom Interstudi terhadap Peningkatan Ekuitas Merek. InterKomunika. https://doi.org/10.33376/ik.v2i2.34

Sugiyono. (2016). Memahami Penelitian Kualitatif. Bandung: Alfabeta.

Todorova, G. (2015). Marketing Communication Mix. Trakia Journal of Science. https://doi.org/10.15547/tjs.2015.s.01.063

Ukaj, F. (2016). Public Relations as Part of Integrated Communication of an Enterprise-Consumer Oriented. Journal of Marketing Management (JMM), 4(1), 67-72. https://doi.org/10.15640/jmm.v3n2a7

Wicaksono, A., Suyadi, I., \& Hidayat, K. (2014). Studi pada Konsumen Mobil Toyota Avanza Tahun 2012 di Auto 2000 Malang Cabang Sukun. Jurnal Adminitrasi Bisnis, 12(2), 1-10.

Widikusyanto, M. J. (2014). Membangun Merek Melalui Marketing Public Relations, Jurnal Manajemen. 3(2).

Yin, R. K. (2014). Case Study Research: Design and Methods (5th ed.). Thousand Oaks, CA: SAGE Publications. 